\title{
Assessment of the impact of Imzouren city's WWTP on the quality of the surrounding groundwater, at the Rif Central (Northern Morocco)
}

Said Benyoussef ${ }^{1,2 *}$, Hossain El Ouarghi ${ }^{2}$, Mourad Arabi $^{3}$, Yassine El Yousfi ${ }^{2}$, Maryam Azirar ${ }^{1}$, Ali Ait Boughrous ${ }^{1,2}$

${ }^{1}$ Research team: Biology, Environment and Health, Department of Biology, Errachidia Faculty of Science and Technology, University of Moulay Ismaïl, Meknes, Morocco.

${ }^{2}$ Research Team: Water and Environment Management, Department of Civil, Energy and Environment Engineering, ENSAH, Abdelmalek Essaadi University, Morocco.

${ }^{3}$ Laboratory for the Improvement of Agricultural Production, Biotechnology and the Environment (LAPABE), Faculty of Sciences, Mohammed Premier University, Oujda, Morocco

\begin{abstract}
The groundwater of the Ghis-Nekor aquifer (Central Rif of Morocco) is the main water resource used by the inhabitants for agricultural and domestic purposes. However, its low quality may affect the health of the consumer and weaken agricultural production. The existence of the WWTP at the level of this plain, makes it a probable source of pollution for these groundwater and requires urgent water managers' intervention. Groundwater pollution in this area may be related to natural, anthropogenic and undefined sources (agricultural and industrial activities). To assess the impact of WWTP effluent on this aquifer, ten well water samples were collected upstream and downstream of this WWTP in 2018, and then analysed for physicochemical quality. Multivariate and principal Component Analysis (PCA) of the results obtained revealed two main components, in which the largest source of total variation being F1 presented at $54.75 \%$. The PCA has visualized two groups that distinguish slightly mineralized well waters upstream to moderately from other wells downstream of the WTTP that are highly mineralized. Generally, the groundwater in the study area is characterized by high levels of salinization. The results of this study may be useful for monitoring and managing groundwater pollution in the study area. Keywords: PCA, Groundwater, Physicochemical quality, Pollution, Rif Central, WWTP.
\end{abstract}

\section{Introduction}

The population continues to grow in developing countries, giving rise to megacities with considerable water needs, considerable wastewater flows and considerable environmental problems. Hence the management and monitoring of water resources must become a priority for these countries [1]. Some previous studies have extensively studied the assessment and impact of treated wastewater on groundwater and irrigation water [2-6] suggesting that treated wastewater or untreated wastewater, could be a source of groundwater pollution resulting in increased health and environmental risks. In Morocco, groundwater resources are estimated at about 4 billion $\mathrm{m} 3$ per year, with nearly 80 groundwater aquifers identified [7].

Water pressure and the intensive exploitation of groundwater for different agricultural, industrial and domestic uses, as well as the discharge of wastewater into rivers and their leaching could have negative impacts on the quality of groundwater and thus reduce their potential for use [8-12].

Groundwater pollution is one of the most discussed issues worldwide, particularly in developing countries, because it deteriorates the quality of water, with the consequences it generates for human health, social welfare as well as the economic progress of nations [13]. The groundwater in our study area is exposed to different sources of pollution, and among them, is the presence of the wastewater treatment plant (WWTP) extensive by natural lagoon of
Beni Bouayach-Imzouren, which can be a source of threat to the water quality of the region. To measure the levels of contamination of the water surrounding the WWTP, we started an impact study of the station through the physicochemical analysis carried out on a set of wells upstream and downstream of the WWTP.

\section{Materials and method}

\subsection{Study area}

The Beni Bouayach-Imzouren wastewater treatment plant is located in the northeastern part of the Ghis-Nekor plain, which occupies an area of $100 \mathrm{~km} 2$, near the left bank of Oued Nekor. In the same site, there is a small industrial area located about $2.5 \mathrm{~km}$ from the Mediterranean Sea. The study area is between $425.14 \mathrm{~N}$ and $3891.84 \mathrm{E}$ (Figure 1).

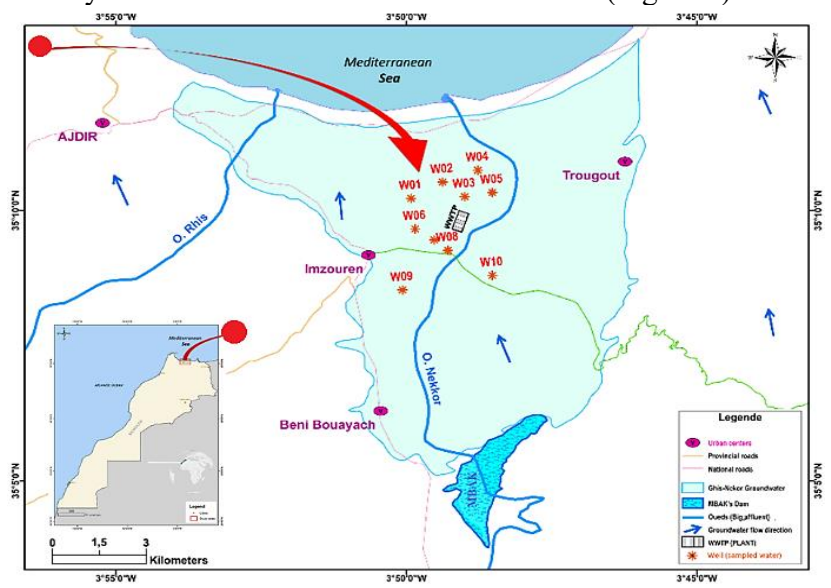

Fig. 1. Sampling locations in Rif Central

*Corresponding author: sa.benyoussef@edu.umi.ac.ma 
According to the 2014 National Population and Housing Census, the studied area's population is estimated to be approximately 52,123 [14]. Also, the piezometric level of the sampled groundwater is shallow, 16.5 to $27.7 \mathrm{~m}$ deep and the most common soil types in the area are mainly clays and/or marls which are sometimes accompanied by silts, sands and/or gravels [15]. However, According to Emberger's diagram, the climate is semi-arid [16], it is characterized by a wet season from October to May, and a dry one from June to September [14] and the distribution of precipitation is irregular in the study area.

The sampling points were identified so as to cover the study area from upstream to downstream of the WWTP. To determine the pollution profile, 10 groundwater samples were taken from 10 representative shallow wells. In the field, temperature, $\mathrm{pH}$, turbidity, salinity, electrical conductivity (EC) and dissolved oxygen (DO) were measured using a handheld multimeter (HANNA, HI 991300), and the piezometric levels (NP) by the piezometric probe. In addition, other samples were taken, in $500 \mathrm{cc}$ polyethylene bottles, and transported, in a portable cooler at $4^{\circ} \mathrm{C}$, to the laboratory, for further chemical analysis. In addition, the concentrations of sodium $\left(\mathrm{Na}^{+}\right)$, potassium $\left(\mathrm{K}^{+}\right)$, sulphates $\left(\mathrm{SO}_{4}{ }^{2-}\right)$ and chlorides $\left(\mathrm{Cl}^{-}\right)$ions, as well as calcium $(\mathrm{Ca} 2+)$ and magnesian $\left(\mathrm{Mg}^{2+}\right)$ hardness were determined in the laboratory in accordance with standards AFNOR and the methods recommended by Rodier [17]. However, the concentrations of $\mathrm{N}_{-} \mathrm{NO}_{3}{ }^{-}$and $\mathrm{N}-\mathrm{NH}_{4}{ }^{+}$were determined by the titrimetric method using a thermo-distillation system (Gerhardt-Vapodest-30-5483-W2-5) [18], while the ion concentration of orthophosphates $\left(\mathrm{H}_{2} \mathrm{PO}_{4}^{-}\right)$was determined by continuous flow analysis (CFA) cited in AFNOR [ISO 15681-2]. Chemical oxygen demand (COD) was analysed by the dichromate oxidation method followed by thermo-digestion in a programmable thermodigester (Behr TRS-300 PA-CSB6, PA-CSB12), whereas, the biochemical oxygen demand $\left(\mathrm{BOD}_{5}\right)$ was assessed using a WTW OxiTop system. In fact, all the methods applied followed the standards of the French Association for Standardization for Wastewater Analysis (AFNOR NF 2000-2001) cited in Chiriac [19]. On the other hand, the spatial distribution of sampling sites is presented on a thematic map, using the Geographic Information System (GIS), while the principal component analysis (PCA) was performed on all the standard data and also SPSS Statistics version 20 software was used for data standardization (Figure 1).

\section{Results and discussions}

The samples collected were analyzed for the 12 elements mentioned in the list presented in Table 1. The results obtained (Table 1) show $\mathrm{pH}$ values between 7.15 and 7.65 with an average of 7.33. All the measures reveal a neutral environment. We also note that the temperature of the groundwater varies from 19.02 to $23.07^{\circ} \mathrm{C}$, with an average value of $21.43^{\circ} \mathrm{C}$. Then, according to Detay Carpenter's groundwater classification [20], the EC values show slightly mineralized water upstream from the
WWTP and moderately to highly mineralised downstream from the station.

Table 1. Physico-chemical data of the groundwater samples in the study area

\begin{tabular}{|l|l|l|l|l|}
\hline \multicolumn{1}{|c|}{ Parameters } & \multicolumn{1}{|c|}{ Units } & Lower & \multicolumn{1}{|c|}{ Upper } & Mean \\
\hline $\mathbf{p H}$ & - & 7,15 & 7,65 & 7,33 \\
\hline $\mathbf{E C}$ & $\mathrm{mS} / \mathrm{cm}$ & 2,02 & 6,54 & 3,90 \\
\hline $\mathbf{T}$ & ${ }^{\circ} \mathrm{C}$ & 19,02 & 23,07 & 21,43 \\
\hline $\mathbf{N a C l}$ & $\mathrm{mg} / \mathrm{L}$ & 1,10 & 3,70 & 2,20 \\
\hline $\mathbf{D O}$ & $\mathrm{mg} / \mathrm{L}$ & 2,26 & 3,27 & 2,86 \\
\hline $\mathbf{C l}^{-}$ & $\mathrm{mg} / \mathrm{L}$ & 465,00 & 1512,30 & 908,96 \\
\hline $\mathbf{N O}_{3}{ }^{-}$ & $\mathrm{mg} / \mathrm{L}$ & 0,39 & 2,50 & 1,71 \\
\hline $\mathbf{N H}_{4}{ }^{-}$ & $\mathrm{mg} / \mathrm{L}$ & 0,21 & 0,90 & 0,51 \\
\hline $\mathbf{N O}_{2}{ }^{-}$ & $\mathrm{mg} / \mathrm{L}$ & 0,07 & 0,16 & 0,11 \\
\hline $\mathbf{S O}_{4}{ }^{2-}$ & $\mathrm{mg} / \mathrm{L}$ & 165,22 & 445,62 & 324,98 \\
\hline $\mathbf{B O D}_{5}$ & $\mathrm{mg} \mathrm{O} / \mathrm{L}$ & 7,70 & 18,30 & 13,26 \\
\hline $\mathbf{C O D}$ & $\mathrm{mg} \mathrm{O} / \mathrm{L}$ & 22,30 & 42,70 & 34,06 \\
\hline
\end{tabular}

According to the results obtained, the high rates of mineralization are probably related to the types of substrates traversed by groundwater reinforced by the infiltration of wastewater [10] from the STEP at the left bank of Oued Nekor. At the same, the salinity is positively correlated with EC from upstream to downstream of the station [8]. However, the Chloride concentrations range from 464 to $1512.30 \mathrm{mg} / \mathrm{L}$, with an average of 908.96 $\mathrm{mg} / \mathrm{L}$. Most of studied samples have chloride concentrations above WHO standards [21], there is also an increase in the sulfate content from upstream to downstream. Furthermore, the concentrations in P3 and P4 exceed the WHO recommended threshold [21], while, the values recorded for nitrogen elements in all samples do not exceed WHO critical levels for drinking water. However, $\mathrm{BOD}_{5}$ and $\mathrm{COD}$ exceeded the maximum limit allowed by WHO [22] with successively 6 and $10 \mathrm{mg} / \mathrm{L}$ in most samples collected.

Table 2. Correlation matrix of physicochemical parameters for the analysed samples in the study area

\begin{tabular}{|c|c|c|c|c|c|c|c|c|c|c|c|c|}
\hline & $\mathrm{pH}$ & EC & T & $\mathrm{NaCl}$ & DO & $\mathrm{Cl}$ & $\mathrm{NO}_{3}$ & $\mathbf{N H}_{\mathbf{A}^{\prime}}$ & $\mathrm{NO}_{2}$ & $\mathrm{SO}_{4}{ }^{2}$ & $\mathrm{DBO}_{5}$ & DCO \\
\hline $\mathrm{pH}$ & 1 & & & & & & & & & & & \\
\hline EC &,- 709 & 1 & & & & & & & & & & \\
\hline T & -865 & ,861 & 1 & & & & & & & & & \\
\hline $\mathrm{NaCl}$ &,- 712 & 1,000 & ,858 & 1 & & & & & & & & \\
\hline DO & ,779 & -,803 &,- 704 &,- 809 & 1 & & & & & & & \\
\hline $\mathrm{Cr}$ & -633 & ,851 & ,888 &, 841 & -506 & 1 & & & & & & \\
\hline $\mathrm{NO}_{3}$ & -487 & ,452 &, 732 & ,447 & -,126 & 687 & 1 & & & & & \\
\hline $\mathrm{NH}_{4^{+}}$ &,- 379 & ,490 &, 509 & ,489 & -,609 & ,469 & ,089 & 1 & & & & \\
\hline $\mathrm{NO}_{2}$ &,- 788 & ,721 & ,656 &, 725 & -961 & , 488 & ,049 & 625 & 1 & & & \\
\hline $\mathrm{SO}_{4}{ }^{2-}$ & -866 & ,749 & ,809, & ,744 &,- 772 & 698 &, 254 &, 542 & ,801 & 1 & & \\
\hline $\mathrm{DBO}_{5}$ &,- 808 & ,874 & ,856 & 873 &,- 912 & ,724 &, 296 &, 730 & ,890 & ,902 & 1 & \\
\hline DCO &,- 887 & ,877 & ,897 & ,875 & -874 & ,763 & 365 & 615, & ,865 & 954 & ,979 & 1 \\
\hline
\end{tabular}

The correlation matrix also showed a strong positive correlation for $\mathrm{BOD}_{5}$ with $\mathrm{COD}(\mathrm{r}=0.979) . \mathrm{BOD}_{5}$ and $\mathrm{BOD}_{5}$ are two key indicators of environmental health and water quality. In our current study, $\mathrm{BOD}_{5}$ is between 7.70 $\mathrm{mg} / \mathrm{L}$ and $18.30 \mathrm{mg} / \mathrm{L}$ and $\mathrm{BOD}_{5}$ is between $22.30 \mathrm{mg} / \mathrm{L}$ and $42.70 \mathrm{mg} / \mathrm{L}$, which exceeds the maximum allowed by WHO drinking water standards. In addition, the first two factors (F1 and F2) constitute approximately $86.81 \%$ of the total deviation. $\mathrm{F} 1$ is carried by $54.75 \%$ of the variability of the data and includes most of the concentrations of the parameters studied with a strong positive charge on the contents of $\mathrm{NH}_{4}{ }^{+}, \mathrm{NO}_{2}^{-}, \mathrm{SO}_{4}{ }^{2-}$, 
$\mathrm{BOD}_{5}, \mathrm{COD}, \mathrm{EC}, \mathrm{NaCl}, \mathrm{Cl}^{-}$, and a negative charge on the dissolved oxygen (DO) (Figure 2). It represents the impact of the dissolution of evaporites as well as discharges from the WWTP on the quality of groundwater in the study area.

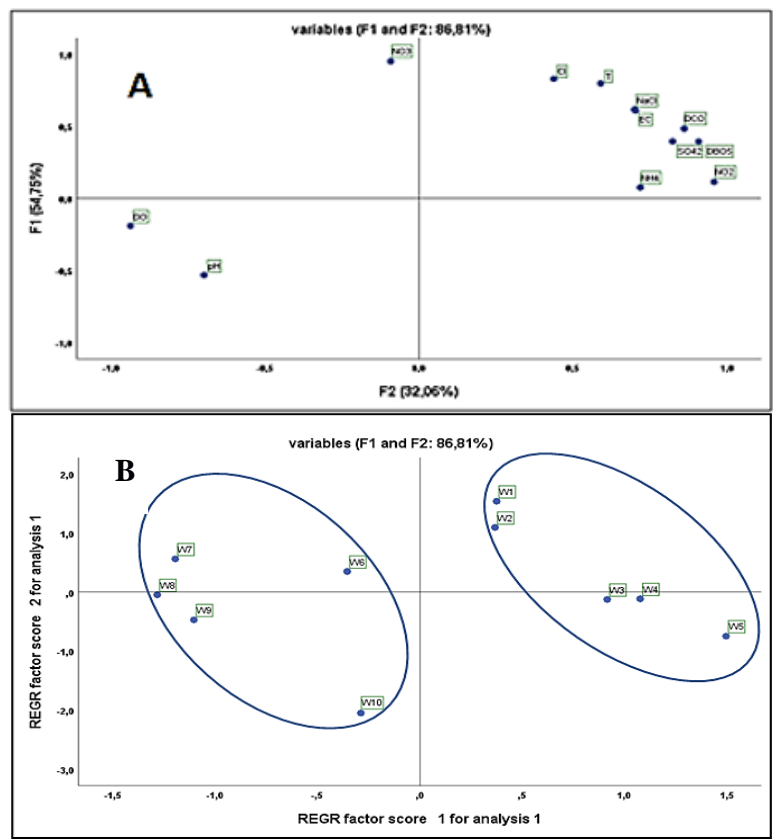

Fig. 2. Projection of variables physicochemical (A) and distribution of the two principal PCs (B) into the factorial plane $(\mathrm{F} 1 \times \mathrm{F} 2)$

In fact, F2 represents $32.06 \%$ of the total variance expressed by a strong positive charge on $\mathrm{NO}_{3}^{-}$linked mainly to human and agricultural activities, to urban development as well as to wastewater [24] whether or not it comes from the WWTP. The distribution of PC scores as shown in Figure 3, shows two separate groups (PCs1 and PCs2). Finally, the PCs1 consists of highly mineralized water from the contaminated field downstream of WWTP, whereas, the PCs 2 corresponds to slightly mineralized samples upstream and downstream of WWTP.

\section{Conclusion}

The results concluded that the pollution of the wells studied increases from upstream to downstream of the WWTP, which could be explained by the impact of the infiltration of wastewater from the natural lagoon treatment plant, waste and discharges from small industrial units located in the study area. Thus, these waters are also characterized by salinization phenomena. This is confirmed by the monitoring of electrical conductivity which has shown that groundwater is well mineralized. The PCA was used to examine the correlation between water quality parameters and their origins to determine the source of pollution. The largest source of variation on F1 $(54.75 \%)$ appears to be from groundwater quality parameters associated with the natural process, defined source pollution (SPSW wastewater), and undefined source pollution (agricultural activities). The results of the PCA confirm exactly the assumptions of our interpretations. It was noted that the site is of major interest for further experimentation due to the transformation of the WWTP from an extensive process (natural lagoon) to an intensive process (activated sludge); this will certainly have positive impacts on the quality of surface and groundwater that will be studied in our next work.

\section{Acknowledgement:}

This paper is part of the CNRST-funded research project entitled "Biodiversity and groundwater quality in the $\mathrm{Al}$ Hoceima region (Northern Morocco): Application to hygiene, monitoring and protection of aquifers".

\section{References}

1. H. Bouwer. J. Environ. Health, 63, 3 (2000)

2. O. Gundaz, C. Simsek, in Wastewater Reuse-Risk Assessment, 159-167 (2007)

3. H. Fathi, M. El-Rawy, Egypt. Poll Res, 37, 1 (2018)

4. M.A. Baghapour, S. Nasseri, B. Djahed, J. Environ. Health Sci. Engineer, 10, 1 (2013)

5. S. Zafar, A, Khan, H. Ullah, M.S. Khan, I. Khan A. Hameed, S. Ur-Rehman, G. Yasmeen, Environ. Monit. Assess, 189, 4 (2017)

6. M. El-Rawy, V.A. Zlotnik, M. Al-Raggad, A. AlMaktoumi, A. Kacimov, O. Abdalla, Environ. Earth Sci, 75, 15 (2016)

7. M. Bzioui, UN Water-Africa. 94, (2004)

8. M. Kadaoui, A. Bouali, M. Arabi, J. Water Land Dev. 42, 1 (2019)

9. H.S.A. Yahya, A. Jilali, M. Battioui, M. Mostareh, C. Belbachir, A. Chafi, J. Mater. Environ. Sci, 6, 9 (2015)

10. A. Fekkoul, Y. Zarhloule, M. Boughriba, A. Barkaoui, A. Jilali, S. Bouri, Arab. J Geosci, 6, 12 (2013)

11. S. Fetouani, M. Sbaa, M. Vanclooster, B. Bendra, Agric. water manage. 95, 2 (2008)

12. R. Benkaddour. (1997)

13. S.M. Sadat-Noori, K. Ebrahimi, A.M. Liaghat, Environ. Earth Sci, 71, 9 (2014)

14. HCP. (2017)

15. A. Salhi. (2008)

16. L. Emberger, Compte rendu hebdomadaire des séances de l'Académie des Sciences, Paris, 191 (1930)

17. J. Rodier, L'analyse de l'eau. Dunod (2009)

18. CEAEQ, 2003th. Ed. Environment ministry of Québec. (2003)

19. R. Chiriac, J. De Araujos Morais, J. Carre, R. Bayard, J.M. Chovelon, R. Gourdon, Waste Manag, 31, 11 (2011)

20. M. Detay, M. Carpenter, Wiley London. (1997)

21. World Health Organization WHO. (2011)

22. World Health Organization WHO. (2008)

23. M. Ben Alaya, T. Zemni, A. Mamou, F. Zargouni, Hydrol. Sci. J, 59, 2 (2014)

24. D. Chafouq, A. El Mandour, M. El Gettafi, M. Himi, I. Chouikri, J. African Earth Sci, 139 (2018) 